\title{
Life in Residential Schools: A Response to Shirley Sterling's My Name is Seepeetza by Desirée Pelletier
}

\begin{abstract}
No one story can capture the diverse experiences of Aboriginal children sent to residential schools. A prospective teacher of Aboriginal descent offers her perspective on the young adult novel, "My Name is Seepeetza," which chronicles a young girl's life at a residential school in the mid-twentieth century. The author compares the experiences of young Martha in the story with those of her own grandmother and other Native children in various Canadian provinces. She suggests that the book is a valuable and accessible introduction to the history of First Nations in Canada.
\end{abstract}

In the introduction to her book, Bone Black: Memories of Girlhood (1996), which she based on her own experiences of growing up black in America, bell hooks states that "there is no one story of a black girl" (1). Similarly, I believe that no one story can portray the diversity of Native people's experiences in Canada, historically, economically and socially. No one story can accurately portray the violent acts of abuse that Native children endured in residential schools. Moreover, no one story can tackle the immense social conditions and economic marginalization that have infested Native communities across Canada as a result of the emotional and mental abuse Native children experienced in these schools. The book My Name is Seepeetza by Shirley Sterling, written from a Native perspective, tells the story of one Aboriginal girl's life at a residential school and is an excellent way to introduce the topic to today's students. The book covers a variety of universal themes such as racism and family relationships, as well as cultural differences and perspectives between the main character, Martha Stone, and the priests and nuns at the residential school that Martha attends. The story is written in a diary form that records Martha's thoughts, feelings, reflections, observations and reactions to her experiences in the residential school in the interior of British Columbia.

As a future teacher of Aboriginal descent, I would like to discuss Martha's experiences and compare them to the darker side of residential schools. Martha was one of the luckier ones; many students died in their first year of school or lost siblings due to diseases. Some were abused either physically or sexually. Others returned home to their families and communities as strangers, unable to speak their own language and unprepared to live life on the reservation. Historians have argued that the quality of education in the residential schools served to marginalize Native people economically 
and politically and to maintain the status quo in Canadian society. Native communities such as the Nuu-chah-nulth are conducting their own studies about the effects of residential schools that offer another perspective that presents a much darker and personal picture of residential schools. It is these personal stories that I have chosen to compare with Martha's experiences.

My great-grandmother was a medicine woman in Saskatchewan. She travelled primarily by horse-drawn wagon and lived in a tipi. Indian policy in Canada required all status and treaty Indian children to attend residential schools. Following this policy, the local Indian agent and RCMP came and took away all five of my great-grandmother's children and sent them to residential school. Only three survived. My grandmother's experiences in the school were drastically different from Martha's experiences in the story. My grandmother was sexually abused during her first year at school, and although she survived her experience, it affected her psychologically. She turned away from her culture, became an alcoholic, and died young from breast cancer. Her brothers would not survive their first year at school. Both died from diseases. When my great-grandmother, Mrs. Okweehow, came back in the spring to pick up her children, there was no happy reunion as there is in Sterling's book. She waited in vain outside the school for her two sons to come out. The nuns had failed to inform my grandmother that her brothers had died, and when they eventually informed my great-grandmother that the boys were dead, they would not tell her where they were buried. There are many more stories much like these.

These stories are important to tell because they are directly related to the economic, social and political marginalization of Native people today. Furthermore, these experiences also help to explain why Native communities today are infested with social problems, and why Native communities and individuals across Canada are suing the government and churches for the physical, sexual and mental abuse that was inflicted upon them in residential schools. It is important, though, to understand that there is a diversity of experiences within a culture. Although my grandmother and many others suffered from the pervasive racial attitudes towards Native tribes in the plains, there are other Native people across Canada who had more positive experiences in residential schools, and it is historically important that we examine their stories as well. 
There are many historical, regional and cultural differences among Native peoples in Canada. For example, provinces such as Alberta, Saskatchewan and Manitoba were more densely populated by non-Native people than the interior of British Columbia where Martha lived. Martha's family in the story owned a ranch, indicating individual ownership of land. This is a concept that is overwhelmingly rejected among the plains' tribes, and explains why there are reserves there today. Native tribes in British Columbia did not sign treaties and not all tribes lived on reservations, although Indian policies did apply to them as well. Martha's father, like many Native parents, realized that their way of life was changing and that their children needed to be educated in order to ensure their survival and adaptation as a nation. They negotiated for education, but did not realize this meant sending their children to residential schools.

The studies conducted by Native communities across Canada today are presenting personal perspectives and experiences that have historically and politically been ignored. In the Northern British Columbia Nuu-chah-nulth study of residential schools, Elders in the community were interviewed about their thoughts, feelings and experiences of residential schools. One of the many social and political themes that emerged from the study was alienation. In the story, when Martha returns home from residential school, she is still close to her mother and father. Many Native students, however, returned home despising their parents for sending them away, and others were ashamed of their parents" "primitive" lifestyle. Those students who did exceptionally well at school often returned home with a feeling of alienation from their own family and community and unable to speak their native language.

Elders in the study spoke of the inferior quality of the education received at residential schools; as a result, students were often not well prepared to compete with non-Native people for jobs off the reservation, and there were no jobs for them on the reservation. Unlike Martha, who was able to return home for the summer holidays and to be reunited with her family and traditions, students from Northern communities were often not able to go home in the summer and would spend years living at the school yearround, separated from their families and communities. Consequently, many would never return home at all. Unable to find jobs, they would eventually find themselves living on the street.

The character, Martha, did not suffer as much as many Native students did in residential schools, but Sterling's book is a valuable way to introduce students today to the experiences of Native peoples in these schools. As a teacher, I feel it is important to point to the great diversity among First Nations in Canada and to stress that Martha's 
story is one among many diverse experiences. The book can help to offer insight into the social problems that Native people face today and help to show that these problems are not because of our inferiority as a nation. I understand that it has been difficult for EuroCanadians to examine their own history and their ancestors' crimes inflicted upon First Nation's peoples; historically and politically, it was easier to suggest that perhaps we suffer from the social problems of today because we are lazy and an inferior race. Such a viewpoint was reinforced by historians and anthropologists who examined our social and political structures from a European perspective to explain why we have become a marginalized society.

I would like to see Sterling's book read in English and Social Studies classes and categorized, not as Native history, but as Canadian history. Her book is an excellent place to start because it is written in a style that is easy for most students to read. It provides readers with historical information that is much easier to access than historical texts written on the subject of residential schools. More importantly, it explores a young girl's thoughts, feelings and observations as she responds to what is happening to her. Although no one story can portray the Native experience in Canada, My Name is Seepeetza tells a significant story that is important to hear.

\section{References}

Hooks, bell. (1996). Bone Black: Memories of Girlhood. New York: Henry Holt and Company. Sterling, Shirley. (1992). My Name is Seepeetza. Toronto: Groundwood.

\section{Editors' Note:}

Further information and reviews of My Name is Seepeetza are available on-line at http://www.amazon.com/exec/obidos/ASIN/0888991657/qid=981527976/sr=11/ref=sc_b_1/107-7649631-5329355

\section{Biography}

Desirée Pelletier is part Cree, Ojibway and French. She grew up in Saskatchewan and is currently completing her B.Ed. at the University of Alberta. She has a strong interest in reading and in bringing issues of culture into her teaching. 